\title{
The Iraqi EFL Learners' Use of Permission, Obligation and Prohibition
}

\author{
Mohammed Jasim Betti ${ }^{1}$, Zainab Kadim Igaab ${ }^{1} \&$ Muna Talib Hussein Al-Ghizzi ${ }^{2}$ \\ ${ }^{1}$ Department of English, College of Education for Humanities, University of Thiqar, Thiqar, Iraq \\ 2 Thiqar Directorate of Education, Thiqar, Iraq \\ Correspondence: Mohammed Jasim Betti, Department of English, College of Education for Humanities, \\ University of Thiqar, Thiqar, Iraq. E-mail: alseady2@gmail.com; zainabigaab@yahoo.com
}

\author{
Received: December 2, 2017 Accepted: December 27, $2017 \quad$ Online Published: February 10, 2018 \\ doi:10.5539/ijel.v8n3p251 \\ URL: http://doi.org/10.5539/ijel.v8n3p251
}

\begin{abstract}
The study aims at specifying the different types of directives available in the literature about speech acts; showing their relationship; and investigating the ability of the Iraqi EFL learners to recognize and produce the aforementioned speech acts. To validate the hypotheses of the study, a test is used to measure the ability of the fourth year subjects, at Thi-Qar University, College of Education for humanities, to recognize and produce permission, obligation and prohibition. It is hypothesized that the Iraqi EFL learners' performance at the recognition level is better than that at the production of permission, obligation and prohibition; their performance of permission at both the recognition and production levels is better than that of obligation and permission; they tend to use some specific linguistic forms which are characteristic of the types of directives. The study concludes that the subjects' performance at the recognition and production levels do not reveal a moderate mastering of permission, obligation and prohibition. In spite of that, their recognition level is better than their production and they have weaknesses at the pragmatic level of the selected directives.
\end{abstract}

Keywords: permission, obligation, prohibition, Iraqi EFL learners

\section{Introduction}

The study deals with three categories of directive speech acts. Directives are defined as "speech acts by which speakers direct or elicit actions by others" (Matthews, 2007, p. 106) or "to get other people to do something for the speaker" (Crystal, 2003, p. 140). In permission, the speaker permits the hearer to do a certain action, in obligation, similarly, the speaker desires to oblige somebody to do something, and in prohibition, the speaker intends to get someone else not to do something.

It is noticed that advanced Iraqi EFL learners face certain difficulties in recognizing and producing directives like permission, obligation and prohibition. It is also realized that the Advanced Iraqi EFL learners have problems in identifying the relationship among the aforementioned speech acts.

The study aims at

1). specifying the different forms of permission, obligation and prohibition available in the literature about speech acts and showing the relationship among their type; and

2). investigating the ability of the Iraqi EFL learners to recognize and produce the aforementioned speech acts.

In the study, it is hypothesized that the Iraqi undergraduate EFL learners;

1). perform better at the recognition level than that at the production one in using permission, obligation and prohibition;

2). have a low performance at the pragmatic level of the selected directives;

3). perform better at both the recognition and production levels of permission than those of obligation and prohibition;

4). are unable to realize the relation among the mentioned speech acts; and

5). tend to use particular linguistic forms to express the cited speech acts. 
The study is limited to permission, obligation and prohibition. It is also limited to the investigation of the Iraqi EFL undergraduate students' recognition and production of permission, obligation and prohibition at the English department, mainly the fourth year students at Thi-Qar University, College of Education for Humanities.

It is hoped that this study will be significant to the Iraqi EFL learners studying English language and linguistics. It also helps the textbook designers design the appropriate situations that include types of directives.

The procedures in this study are:

1). Conducting a test to Iraqi fourth year university EFL learners at the English department/ Thi-Qar University, College of Education for Humanities.

2). Showing the test form to the jury members to examine its validity.

3). Making a pilot test to guarantee the practicality of the test.

4). Carrying out the main test and analyzing its results.

\section{Literature Review}

\subsection{The Structure, Meaning and Pragmatics of Permission}

Permission is defined as giving or asking for somebody's agreement to do or have something. Thomson (1996: 59) sees permission as "the lowest degree of pressure, opening the possibility for other persons to do the action but leaving the decision to them".

Permission could be asked or given. In asking for permission, the speaker has no authority over the hearer, but rather s/he seeks for permission to do an action. In other words, asking for permission is the act of wanting to know whether a person can do something or use something or not. Giving permission, on the other hand, reflects the fact that the speaker has personal authority over the hearer:

(1) You can use my phone if you like.

When permission is not being asked or given, it can be talked about (Eastwood, 1994, p. 120). This could be done by the use of modal auxiliaries:

(2) I can stay up as late as I like. My parents do not mind.

Permission is expressed by the following devices:

1). Allow, Permit and Let

(3) Will you permit (allow) me to use your bicycle?

"Allow" and "permit" are usually used to indicate permission in the past and future time (ibid):

(4) During the curfew, nobody was allowed to be out after sunset.

(5) Shall we be allowed (permitted) to stay up late on new year's Eve? (Hornby, 1968, p. 220).

Praninskas (1975, p. 234) states that when the speaker is talking about permission on a specific occasion in the past, the following constructions are used: the noun "permission" and the verbs "allowed and permitted":

(6) Miss Liu had permission to leave class early.

Quirk et al. (1985, p. 222) and Hannouna (2008, p. 122) affirm that the negation of "allowed to (permitted)" gives the meaning of prohibition:

(7) You are not allowed to borrow my car.

Imperative sentences are also employed to grant permission:

(8) Come in.

The speaker does not issue a command, but rather s/he is granting the person, who has knocked the door, the permission to enter the room. Her/his knocking is considered as a request of our permission:

(9) May I come in? (Lyons, 1977, p. 837).

Furthermore, nominal and adjectival expressions denote the meaning of permission. These include the noun "permission" and the adjectives "permissible and allowed" (Jackson, 1999, p. 104) and (Gramley \& Patzold, 1992, p. 157):

(10) It is permissible/allowed for me to build here.

In the same regard, Leech \& Svartvik (1994, p. 163) add the use of the verb "mind" to give and ask for 
permission:

(11) Would you mind if I opened a window.

2). Modal Auxiliaries

Some modal auxiliaries describe permission (can/ could and may/ might). Several meanings are expressed by modal auxiliaries: permission, obligation, probability, certainty, ability, etc. (Quirk \& Greenbaum, 1990, p. 60):

(12) Can we borrow these books from the library?

Furthermore, "could" is considered as more tentative than "can" when it is used to ask for permission.

(13) Could you help me with this math problem?

"Might" is more tentative than "may". Swan (1995, p. 318) supports such an idea, adding that "might" is used in the indirect $\mathrm{Q}$ structures:

(14) Might I smoke in here?

Huddleston (1988, p. 78) and Berk (1999, p. 131) affirm that permission, obligation and prohibition are parts of deontic modality. Sag \& Wasow (1999, p. 65) add that permission is related to possibility in the same way that obligation is related to necessity. That is, deontic necessity identifies what someone is required to do, while deontic possibility explains what behavior is permissible.

In so far as the pragmatics of Permission is concerned, reference is made to speech act theory, felicity condition of permission, explicit and implicit types of permission,

\section{a. The Notion of Speech Act Theory}

The purpose of speech in a given context is to generate some kind of action. Every sentence is structured to carry certain intention. Intentional human action is the concern of pragmatics. Intentional action is intended to achieve a goal, through some kind of plan, give some beliefs about state of things. This results in "speech acts" that are carried out directly or indirectly. When speaking, all sorts of things can be done, from aspirating a consonant, to constructing a relative clause, to insulting a guest, to starting a war. These are all speech acts. Speech act theory has been one of the basic ingredients of pragmatics for a long time. It was first proposed by Austin and developed by Searle. Austin (1962, p. 8) defines a speech act as "the act of uttering a certain sentence in a given context for a determined purpose". Speech act theory views utterances not just as stating propositions but as a way of doing things with words acts (Finch, 2005, p. 171).

Austin draws a distinction between explicit performative and implicit performative. According to Parker \& Riley (2005, p. 18) "the term explicit performative describes an utterance that contains a performative verb used in its performative sense". Explicit performative, on the one hand, is one in which the utterance- inscription contains an expression that indicates the kind of the act being acted or performed (Lyons, 1995, p. 239). This means that there is a linguistic signal whose function is to denote illocutionary force. Schiffer (1972, p. 105) and Yule (1996, p. 51) affirm that an explicit performative sentence begins with a verb in the first person singular present indicative active. "I (hereby) order you to leave" and "I hereby promise to pay you two pence". Two types of explicit performative could be identified: lexical and grammatical (Cruse, 2000, p. 333).

Austin (1962, p. 155) contends that permission belongs to the exercitive category of speech act because arbitrators and judges make use of exercitives as well as issuing directives. Similarly, Searle (1979, p. 13) states that permission is considered as a kind of directives which are attempts to get the hearer to do something. Permissions, on the one hand, are defined as the "illocutionary negations of orders" (in other words, a sentence like "I give you permission to leave" is equivalent to a sentence like "I do not order you not to go"). On the other hand, permissions are defined as "the illocutionary negation of prohibitions" that it is done (in other words, a sentence like "I give you permission to go" is equivalent to a sentence like "I do not forbid you to go" (Tsohatzidis, 1987, p. 80).

\section{b. Felicity Conditions of Permission}

Hurford \& Heasley (1983, p. 251) define the felicity conditions of an illocutionary act as "conditions that must be fulfilled in the situations in which the act is carried out if the act is to be said to be carried out properly."

Here are the felicity conditions as listed by Searle (1969, p. 23) for asking permission (Allan, 1986, p. 199):

1). Propositional content: the speaker seeks the hearer's acceptance to do or have a certain act.

2). Preparatory condition: the speaker believes that he/she is sanctioned to seek the hearer's permission before doing an act. 
3). Sincerity condition: the speaker believes that he/she may do an act depending on the hearer's authority.

4). Essential conditions or illocutionary point: the speaker intends his/her utterance to be recognized as a request for the hearer to accept his act.

\subsection{The Structure, Meaning and Pragmatics of Obligation}

Obligation is considered as one of the directive speech acts. It is the speaker's intention to oblige somebody (not) to do some acts. Palmer (1990, p. 124) states that "the speaker is presuming that $\mathrm{s} / \mathrm{he}$ has (physical, psychological or institutional) authority over the hearer that gives such weight or power to his/her utterances". It implies some kind of necessity, i.e., obligating somebody or oneself to do something means it is necessary that the action in $\mathrm{Q}$ is performed.

Obligation can be performed through the use of various devices:

\section{a. Declarative Sentences}

A declarative sentence refers to verb forms or sentence/ clause types usually used in the expression of statements":

(15) The man is walking.

\section{Be+ to+ infinitive}

Hornby (1968, p. 210) Chalker (1984, p. 83), Eastwood (1994, p. 100) and Foley \& Hall (2003, p. 183) affirm that the construction " $\mathrm{Be}+$ to + infinitive" carries the meaning of obligation in which the orders are given by the speaker who has some official authority:

(16) You are to write your name at the top of each page.

\section{Be + supposed to}

This construction denotes the idea of "duty and obligation" which is normally used to express what people must do according to rules (Thomson \& Martinet, 1980, p. 268; Biber et al., 1994, p. 500; and Yule, 2006, p. 41):

(17) You are supposed to start working at 8.30 every morning.

It also indicates an obligation to achieve some promises and expectations (Dixon, 1987, p. 94). The meaning is usually passive because the subject is expected or supposed by someone else to carry out the action:

(18) Helen is supposed to arrive tomorrow.

\section{Need (to)+infinitive}

Obligation could also be obtained by the use of "need (to) + infinitive," in which "need" is the main verb (Quirk et al., 1985, p. 138). "Need" could have different possible forms when it denotes obligation and it could be used in the past or present:

(19) I need a new suit .

\section{Infinitive clauses}

Quirk et al. (1985, p. 1052) and Swan (1995, p. 273) believe that infinitive clauses have an obligational sense. "What" is one of the infinitive clauses that explain such a meaning:

(20) I do not know what to say.

This sentence is explained as "I do not know what I should say". Also, "why" is rarely used to give such a sense:

(21) I am wondering why to go at all,

which could be understood as "I am wondering why I should go at all". Furthermore, the construction "noun+ infinitive (to+ infinitive)" could also indicate the notion of obligation (Swan, 1995, p. 274):

(22) I have got letters to write.

\section{Indirect Questions}

Indirect Qs can express the sense of obligation. Schibsbye (1970, p. 76) and Quirk et al. (1985, p. 1052) confirm that "Wh-Q+ infinitive (to $+\mathrm{v}$.)" is a structure to denote obligation in indirect speech:

(23) I wonder who to invite. (...who I should invite)

\section{b. Interrogative Sentences}

Interrogations are normally yes-no, or wh-interrogatives but sometimes they are not used to raise Qs, but express 
the meaning of obligation (Arts, 2001, p. 60):

(24) How many times do I have to tell you not to lick your plate.

Moreover, adjectival expressions "compulsory, obligatory and necessary", and verbs: "oblige", "compel", "require" and "be liable to" are also used to convey the meaning of obligation (Hornby, 1968, p. 216; Perkins, 1983, p. 85; and Foley \& Hall, 2003, p. 183):

(25) Military service is compulsory in many countries.

"Have (got) to" is a semi-auxiliary verb which is capable of functioning as an auxiliary and a lexical verb. It is regularly used to express obligation. Clarke (2008, p. 74) states that "have (got) to" is used when "commenting on something which is important or obligatory because of a law or a rule or because someone else says it":

(26) Children have to start school when they are five. [It is the law]

Ought to and Should denote the meaning of obligation and logical necessity, but they are less categorical than "must" and "have to" (Quirk \& Greenbaum, 1990, p. 55).

"Shall" conveys a sort of self-imposed obligation with the first person pronouns and the results would be a promise or a threat (Chalker, 1984, p. 121):

(27) We shall come about 3:00 p.m.

Leech \& Svartvik (1994, p. 165) confirm that "shall" in the meaning of obligation is restricted to official regulations and other formal documents:

(28) The society's nominating committee shall nominate one person for the office of president.

Locke (1996, p. 206) affirms that "will" expresses a sense of obligation. It implies "sufficiently strong authority on the part of the speaker to ensure that there is almost no doubt the obligation will be complied with":

(29) You will carefully and clearly give your address and cross the street. Moreover, "will" in certain prediction uses has the sense of obligation:

(30) The game will /must/ should be finished by now.

As related to the pragmatics of obligation is concerned, obligation has a sense of necessity in such a way that obliging someone to do something means that it is necessary for him/her to perform the action. Three conditions must be fulfilled to achieve the sense of obligation:

a. The speaker must has the authority to do an action.

b. The action is permitted .

c. The hearer has to be perceived to have the ability to carry out the action.

Fraser (1987, p. 187) distinguishes the following principles to consider the act as obligation:

a. Principle of unspecified time, i.e., when the time of an action is not specified, one can infer that the agent is expected to perform that action at the earliest chance.

b. Principle of efficiency, i.e., whenever an utterance is redundant, one can infer that the speaker does not need to make the utterance, but he would operate as if he/she had made it and expected the hearer to operate at the same way.

c. Principle of obligation fulfillment, i.e., when someone is obliged to perform an act, one can predict that s/he will perform that action.

Depending on the felicity conditions of requirements stated by Allan (1986, p. 199), the following felicity conditions are drawn for an act to be realized as an obligation:

i. The speaker obliges the hearer to do an act.

ii. The speaker has reasons to believe that the hearer can do an act.

iii. The speaker wants the hearer to do an act.

iv. The speaker reflexively - intends the utterance to be recognized as a requirement on the hearer to do an act.

\subsection{The Structure, Meaning and Pragmatics of Prohibition}

Prohibition is defined as a speakers intention to prevent the hearer from performing certain actions. It consists of two main types: preventive and cessative. Preventive prohibition includes impostive speech acts carried out so as to forbid a certain state of affairs from being performed (Haverkate, 1979, p. 39). The following example 
(31) Do not tell him what happened when he comes,

indicates preventive prohibition, i.e., the speaker prevents the hearer from transmitting the situation in which the saying has not taken place to another world in which it has happened. The preventive prohibition can be paraphrased by using a compound sentence. The compound sentence consists of an embedded clause denoting the original prohibition, and a main clause including the verb "avoid". The following example

(32) Do not tell him what happened when he comes,

can be paraphrased as:

(33) Avoid telling him what happened when he comes.

Moreover, Haverkate $(1979$, p. 39) recognizes that such a type of prohibition which has a connection with warning. The relation can be formed in terms of "markedness", i.e., it is the unmarked member of the position and warning is the marked one. It is worthy to mention that the marker distinguishes warning is reflected by the implicit reference to the authority. Therefore, warning has a stronger illocutionary force than preventive prohibition. The following example is regarded as a marked paraphrases of "Avoid telling him ..."

(34) I warn you not to tell him what happened when he comes.

Cessative prohibition, on the other hand, is used when a world is transmitted, in which a certain state of affairs transforms into another world where the state of affairs does not hold (ibid), as the following example shows:

(35) Do not laugh!

This type of prohibition can be paraphrased in ways that the preventive one cannot. Thus,

(36) Do not talk,

The structure of prohibition consists of the following constructions:

\section{a. Imperatives}

The imperative is defined as a grammatical mood which is mainly used to denote command. Imperatives form requirements and prohibitions (Allan, 1986, p. 205). Thus, they are one of the means to express prohibition:

(37) Tell me your name. (requirement)

\section{b. Be+ not + to + infinitive}

Another construction for conveying prohibition is the structure "Be+ not + to + infinitive" (Hornby, 1968, p. 204; and Allen, 1974, p. 34):

(38) He is not to come before seven.

As for the meaning of prohibition, the following auxiliaries express the meaning of prohibition:

(39) The staff must not smoke when sewing customers.

\section{Felicity Condition of Prohibition}

Allan (1986, p. 199) lists the following felicity conditions for the act to be realized as a prohibitive act:

1). The propositional content: the speaker prohibits the hearer from doing an act.

2). The preparatory condition: the speaker has a reason to believe that the hearer should not do an act.

3). The sincerity condition: the speaker wants the hearer not to do an act.

4). The essential condition or illocutionary point: the speaker reflexively intends the utterance to be realized as a requirement to do an act.

\section{Method}

This study aims at discovering and identifying the ability of the Iraqi EFL learners to recognize and produce permission, obligation and prohibition. In order to achieve this, the researcher constructs a test. The test contains sixty items.

\subsection{Objectives of the Test}

In order to achieve the objectives of the study and verify its hypotheses, a test has been constructed to investigate the extent to which the university students master the use of permission, obligation and prohibition. The test is a diagnostic one which aims at measuring the subjects' ability to identify permission, obligation and prohibition at the recognition and production levels. It also aims at discovering the subjects' ability to realize the relationship among permission, obligation and prohibition. 


\subsection{The Subjects of the Study}

The total number of the subjects who participate in the test of the study is seventy five, fifty five women and twenty men. Their ages are 22-30. All of them are university college of education dept. of English students who have no native English language background with similar socio-economic background. They have no failure in the department of English.

\subsection{Test Construction, Description and Validity}

The items used in the test are selected from Quirk et al. (1985), Eastwood (1995) and Foley \& Hall (2003). The items cover the different forms that are used to convey the meaning and use of permission, obligation and prohibition.

To have an objective measurement for the evaluation of the subjects' responses, the test is constructed according to the recognition and production levels (see Appendix A). After constructing the test, it was sent to the jury members to examine its validity (Note 1).

The test consists of six questions. Each question consists of ten items. The first three questions are designed to measure the subjects' responses at the recognition level, and the last three ones measure the subjects' performance at the production one.

The items of Q1 are intended to measure the subjects' ability to choose the most appropriate answer for each item in the question. The subjects are given four choices in which only one choice is correct.

The subjects are asked to circle the suitable meaning for each item in Q2. Similarly, Q3 investigates the subjects performance at the recognition level. The subjects are given a table which includes two columns. What the subjects have to do is match the underlined verbs in column A to their appropriate meanings in column B. In Q4, the subjects are given situations and asked to write the appropriate answer. This is applicable for Q5 while Q6 requires the subjects to rephrase the notes and sentences in such a way that it gives the same meaning as the note or sentence indicates. They aim at showing the subjects' performance at the production level on the one hand, and obligation and prohibition on the other hand.

\subsection{Validity and Practicality of the Test}

In order to get the validity of the test in this study, it has been examined by the jury members. The jury members added some items, deleted some others and made a balance between the syntactic and pragmatic items at the recognition and production level. Furthermore, the test should be easy to design and easy to administer. Therefore, a pilot test is conducted to achieve the following:

1). to know the time needed for the administration of the test;

2). to have an idea about the requirements and arrangements for the final administration of the test;

3). to make any necessary modifications for the final administration of the test to determine its suitability and efficiency.

The pilot test is applied on fifteen fourth year subjects who are chosen randomly from the department of English, College of Education for Humanities, University of Thi-Qar. The subjects are told about the purpose of the test and are encouraged to ask for any clarification. After conducting the pilot test, it has been proved that the time required for the final test is one hour and a half.

\subsection{Administration of the Main Test}

The main test is administrated on the twenty- third of April during the academic year 2016-2017. The time specified for the test is one hour and a half. The subjects were motivated to answer as spontaneously and seriously as possible. Explanations were willingly given to the subjects to fully understand what they had to do.

Moreover, the subjects were asked to answer the questions on the test paper and free to write their names or not. The subjects were informed that the test had no effect on their marks. The researcher herself carried out the process of scoring the answers and it was not influenced by any subjective judgments.

\subsection{Scoring Scheme and the Mathematical Means}

The test is scored out of (120). Each question is assigned (20) scores, two scores are given to each correct item and zero for each incorrect one. Blank items are considered correct since they indicate that the subjects fail to answer those items Table 1): 
Table 1. Distribution of the scores of the test

\begin{tabular}{lll}
\hline No. of Qs & No. of Test Items & Marks \\
\hline 1 & 10 & 20 \\
2 & 10 & 20 \\
3 & 10 & 20 \\
4 & 10 & 20 \\
5 & 10 & 20 \\
6 & 10 & 20 \\
Total & 60 & 120 \\
\hline
\end{tabular}

The mathematical means used for calculating numbers are simple calculation and the percentage only. The process of calculation is done as follows:

$\mathrm{M}=\mathrm{X} / 675 * 100 \%$ Where:

$\mathrm{M} \rightarrow$ the mean

$\mathrm{X} \rightarrow$ the number of responses

$675 \rightarrow$ the number of the informants multiplied to the number of the items of the test, i.e., 75.

\section{Results}

This section aims to analyze and identify the Iraqi EFL learners' correct responses and incorrect ones. Permission, obligation and prohibition responses are analyzed and discussed at the recognition and production levels.

\subsection{Analysis of Permission in the Data}

\subsubsection{The Subjects' Responses of Permission at the Recognition Level}

All the subjects' responses of permission at the recognition level are displayed in Table 2:

Table 2. The subjects' performance of permission at the recognition level

\begin{tabular}{lllll}
\hline No. of Items & \multicolumn{2}{l}{ Correct Responses No. \% } & \multicolumn{2}{l}{ Incorrect Responses No. \% } \\
\hline 2 & 64 & 48 & 36 & 27 \\
4 & 93.4 & 70 & 6.6 & 5 \\
7 & 72 & 54 & 28 & 21 \\
2 & 86.6 & 65 & 13.4 & 10 \\
3 & 8 & 6 & 92 & 69 \\
4 & 30.6 & 23 & 69.4 & 52 \\
2 & 82.6 & 62 & 17.4 & 13 \\
5 & 44 & 33 & 56 & 42 \\
9 & 42.6 & 32 & 57.4 & 43 \\
Total & 58.22 & 393 & 41.78 & 282 \\
\hline
\end{tabular}

The table indicates that the total percentage of the correct responses is $58.22 \%$, which means that a good number of the subjects are able to recognize permission. The item that gets high correct responses at the recognition level is item No.4 in the first Q. 93.04\% of the subjects choose "can" to ask for permission. The reason for such a high percentage is the subjects' studying of modal auxiliaries and their uses at the third stage. In addition, item No. 2 in Q2 (86.06\%) is responded to by the subjects as they know that "would you mind" expresses the sense of permission.

As the table shows, item No.3 in question 1 has the lowest percentage among all the other percentages at the recognition level. $92 \%$ of the subjects fail to observe that the imperative sentence conveys a sense of permission. The reason for such failure could be due the subjects ignorance of such a fact because in the grammar courses the learners were not such a syntactic subject.

\subsubsection{The Subjects' Responses of Permission at the Production Level}

As clear in Table 3 below, the subjects' responses to permission at the production level illustrate that the total percentage of the correct responses is $44.14 \%$ which means that a big number of the subjects have problems in the production part of permission: 
Table 3. The subjects' performance of permission at the production level

\begin{tabular}{lllll}
\hline No. of Items & \multicolumn{2}{l}{ Correct Responses No. \% } & \multicolumn{2}{l}{ Incorrect Responses No. \% } \\
\hline 1 & 33 & 44 & 42 & 56 \\
2 & 30 & 40 & 45 & 60 \\
6 & 43 & 57.4 & 32 & 42.6 \\
4 & 55 & 73.4 & 20 & 26.6 \\
5 & 33 & 44 & 42 & 56 \\
8 & 30 & 40 & 45 & 60 \\
3 & 17 & 22.6 & 58 & 77 \\
6 & 42 & 56 & 33 & 44 \\
9 & 15 & 20 & 60 & 80 \\
Total & 298 & 44.14 & 377 & 55.86 \\
\hline
\end{tabular}

The subjects' responses to items No.1, 2 and 6 in the question4 reveal that the subjects do not differentiate between "may" and "can". Both of them are correct in conveying permission, but what differentiates them is the type of situation. The subjects do not know that "can" is less formal than "may". The reason is that they do not pay attention to such a difference, even though there is a mentioning to such information in their grammar textbook at the third stage which is A University Grammar of the English Language by Quirk \& Greenbaum (1973).

Item No.4 in Q5 gets the highest correct percentage in that 73.04\% of the subjects are able to replace "can" by "would you mind" taking into consideration the possible changes. This means that the subjects are structurally good in producing permission. Moreover, the subjects' responses to item No.5 prove that the subjects do not differentiate between giving and asking for permission. This means that the subjects have weaknesses at the pragmatic level of permission. After reviewing all the subjects' responses of permission at the recognition and production levels, it becomes clear that the subjects' performance at the recognition level is better than that at the production level. The subjects' correct responses at the recognition level make $58.22 \%$ of the subjects while $44.14 \%$ subjects provide correct responses at the production level.

Likewise, the subjects have achieved a low performance in distinguishing between asking and giving permission (Table 4):

Table 4. The subjects' performance of permission at the recognition and production levels

\begin{tabular}{|c|c|c|c|c|c|c|c|c|c|}
\hline \multirow[t]{2}{*}{ No. of item } & \multicolumn{2}{|c|}{$\begin{array}{l}\text { Recognition } \\
\text { Correct Responses }\end{array}$} & \multicolumn{2}{|c|}{$\begin{array}{l}\text { Recognition } \\
\text { Incorrect Responses }\end{array}$} & \multirow[t]{2}{*}{$\begin{array}{l}\text { No. of } \\
\text { Item }\end{array}$} & \multicolumn{2}{|c|}{$\begin{array}{l}\text { Production } \\
\text { Correct Responses }\end{array}$} & \multicolumn{2}{|c|}{$\begin{array}{l}\text { Production } \\
\text { Incorrect Responses }\end{array}$} \\
\hline & No. & $\%$ & No. & $\%$ & & No. & $\%$ & No. & $\%$ \\
\hline 2 & 48 & 64 & 27 & 36 & 1 & 33 & 44 & 42 & 56 \\
\hline 4 & 70 & 93.4 & 5 & 6.6 & 2 & 30 & 40 & 45 & 60 \\
\hline 7 & 54 & 72 & 21 & 28 & 6 & 43 & 57.4 & 32 & 42.6 \\
\hline 2 & 6 & 3 & 69 & 92 & 4 & 55 & 73.4 & 20 & 26.6 \\
\hline 3 & 65 & 86.6 & 10 & 13.4 & 5 & 33 & 44 & 42 & 65 \\
\hline 4 & 23 & 30.6 & 52 & 69.4 & 8 & 30 & 40 & 45 & 60 \\
\hline 2 & 62 & 82.6 & 13 & 17.4 & 3 & 17 & 22.6 & 58 & 77.4 \\
\hline 5 & 33 & 44 & 42 & 56 & 6 & 42 & 56 & 33 & 44 \\
\hline 9 & 32 & 42.6 & 43 & 57.4 & 9 & 15 & 20 & 60 & 80 \\
\hline Total & 393 & 58.2 & 282 & 41.78 & Total & 298 & 44.14 & 377 & 55.86 \\
\hline
\end{tabular}

\subsection{An Analysis of Obligation in the Data}

\subsubsection{The subjects' Responses of Obligation at the Recognition Level}

According to table (5) below, the total percentage of the subjects' correct responses at the recognition level is $42.96 \%$ as most of the subjects are unable to recognize obligation. The table displays that the items that have highly correct responses are No.3 in Q1 (73.4\%) and No.8 in Q2 (76 \%). The subjects' responses to both items show that they have the ability to pick up "must" and "be+ to + inf." to express the notion of obligation: 
Table 5. The subjects' performance of obligation at the recognition level

\begin{tabular}{lllll}
\hline No. of item & \multicolumn{2}{l}{ Correct Responses No. \% } & \multicolumn{2}{c}{ Incorrect responses No. \% } \\
\hline 3 & 55 & 73.4 & 20 & 26.6 \\
6 & 44 & 58.6 & 31 & 41.3 \\
9 & 46 & 61.4 & 29 & 38.6 \\
5 & 0 & 0 & 75 & 100 \\
8 & 57 & 76 & 18 & 24 \\
10 & 26 & 34.6 & 49 & 65.4 \\
3 & 16 & 21.4 & 59 & 78.6 \\
6 & 19 & 25.4 & 56 & 74.6 \\
8 & 27 & 36 & 48 & 64 \\
Total & 290 & 42.96 & 385 & 57.04 \\
\hline
\end{tabular}

Item No. 5 in Q2 has the lowest percentage at the recognition level (i.e., 0\%). Moreover, $65.4 \%$ of the subjects fail to realize that "will" includes the sense of obligation, and it is also noted from the responses to items No.3, 6 and 8 in Q3 that most subjects signal difficulties in recognizing obligation pragmatically. This could be due to many reasons, one of which is that there is not any comprehensive explanation to such an area in the syllabus. Furthermore, the teachers and the students have not focused on the pragmatic side of obligation.

\subsubsection{The Subjects' Responses of Obligation at the Production Level}

According to the table, the percentage of the correct responses is $37.18 \%$ while that of the incorrect answers is $62.81 \%$. This reveals that a big number of the subjects encounter difficulties at the production level of obligation (See table 6):

Table 6. The subjects' performance of obligation at the production level

\begin{tabular}{lllll}
\hline No. of item & \multicolumn{2}{l}{ Correct Responses No. \% } & \multicolumn{2}{l}{ Incorrect responses No. \% } \\
\hline 4 & 42.6 & 32 & 57.4 & 43 \\
8 & 17.4 & 13 & 82.6 & 62 \\
10 & 10.6 & 8 & 89.4 & 67 \\
1 & 12 & 9 & 88 & 66 \\
3 & 69.4 & 52 & 36.6 & 23 \\
9 & 86.6 & 65 & 13.4 & 10 \\
4 & 22.6 & 17 & 77.4 & 58 \\
7 & 41.4 & 31 & 58.6 & 44 \\
10 & 32 & 24 & 68 & 51 \\
Total & 37.18 & 251 & 62.81 & 424 \\
\hline
\end{tabular}

The items that have high correct answers are items No.3 and 9 in Q5 and the items that get high incorrect responses at the production level are (item No.8 and 10 in Q4, item No.1 in Q5 and, item No.4 in Q6). The responses to item No.8 show that sixty two $(82.6 \%)$ subjects fail to understand the situation as obligation which leads them to provide incorrect responses. The reason behind that is there is no emphasis given to such area in the textbooks which they study. Similarly, item No.1 in Q5 reveals that 88\% subjects do not know that "had to" expresses the meaning of obligation in the past. After reviewing all the subjects' responses at the recognition and production levels, it is evident that although the subjects' performance at the two levels is poor, it could be said that their performance at the recognition level $(42.96 \%)$ is better than that at the production one $(37.18 \%)$.

Table 7. The subjects' performance of obligation at the recognition and production levels

\begin{tabular}{|c|c|c|c|c|c|c|c|c|c|}
\hline \multirow[t]{2}{*}{$\begin{array}{l}\text { No. of } \\
\text { item }\end{array}$} & \multicolumn{2}{|c|}{$\begin{array}{l}\text { Recognition } \\
\text { Correct Responses }\end{array}$} & \multicolumn{2}{|c|}{$\begin{array}{l}\text { Recognition } \\
\text { Incorrect Responses }\end{array}$} & \multirow[t]{2}{*}{$\begin{array}{l}\text { No. of } \\
\text { Item }\end{array}$} & \multicolumn{2}{|c|}{$\begin{array}{l}\text { Production } \\
\text { Correct Responses }\end{array}$} & \multicolumn{2}{|c|}{$\begin{array}{l}\text { Production } \\
\text { Incorrect Responses }\end{array}$} \\
\hline & No. & $\%$ & No. & $\%$ & & No. & $\%$ & No. & $\%$ \\
\hline 3 & 55 & 73.4 & 20 & 26.6 & 4 & 32 & 42.6 & 43 & 57.4 \\
\hline 6 & 44 & 58.6 & 31 & 41.4 & 8 & 13 & 17.4 & 62 & 82.4 \\
\hline 9 & 46 & 61.4 & 29 & 38.6 & 10 & 8 & 10.6 & 67 & 89.4 \\
\hline 5 & 0 & 0 & 75 & 100 & 1 & 9 & 12 & 66 & 88 \\
\hline 8 & 57 & 76 & 18 & 24 & 3 & 52 & 69.4 & 23 & 36.6 \\
\hline 10 & 26 & 34.6 & 49 & 65.4 & 9 & 65 & 86.6 & 10 & 13.4 \\
\hline 3 & 16 & 21.4 & 59 & 78.6 & 4 & 31 & 41.4 & 44 & 58.6 \\
\hline 6 & 19 & 25.4 & 56 & 74.6 & 7 & 31 & 41.4 & 44 & 58.6 \\
\hline 8 & 27 & 36 & 48 & 64 & 10 & 24 & 32 & 51 & 68 \\
\hline Total & 270 & 42.9 & 385 & 57.04 & Total & 251 & 37.18 & 424 & 62.81 \\
\hline
\end{tabular}




\subsection{An Analysis of Prohibition in the Data}

\subsubsection{The Subjects' Responses of Prohibition at the Recognition Level}

The table indicates that the total percentage of the correct responses of the subjects' responses to prohibition at the recognition level is $45.03 \%$ while that of the incorrect responses is $54.97 \%$ (Table 8 ):

Table 8. The subjects' performance of prohibition at the recognition level

\begin{tabular}{lllll}
\hline No. of item & \multicolumn{2}{l}{ Correct Responses No. \% } & \multicolumn{2}{l}{ Incorrect responses No. \% } \\
\hline 1 & 61.4 & 46 & 38.6 & 29 \\
5 & 81.4 & 61 & 18.6 & 14 \\
8 & 62.6 & 47 & 37.4 & 28 \\
1 & 72 & 54 & 28 & 21 \\
6 & 36 & 27 & 64 & 48 \\
9 & 30.6 & 23 & 69.4 & 52 \\
1 & 17.4 & 13 & 87.6 & 62 \\
4 & 24 & 18 & 76 & 57 \\
7 & 20 & 15 & 80 & 60 \\
Total & 45.04 & 304 & 54.97 & 371 \\
\hline
\end{tabular}

It also shows that the items that get high correct responses are item No.5 in Q1 and item No. 1 in Q2. It is clear that the subjects know that "must not" and "No + ing" express the meaning of prohibition. In the same respect, the general results to items No.6 and 9 in Q2 and items No. 1,4 and 7 in Q3 reveal the subjects' failure to observe that "are not supposed to" and "have not to" convey the meaning of prohibition, and also are unable to realize the meaning and use of prohibition.

\subsubsection{The Subjects' Responses of Prohibition at the Production Level}

The table shows that the percentage of the correct responses to the production of prohibition is $37.18 \%$ compared to that of the incorrect responses is $62.82 \%$ as shown in Table 9:

Table 9. Subjects' performance of prohibition at the production level

\begin{tabular}{lllll}
\hline No. of item & \multicolumn{2}{l}{ Correct Responses No. $\%$} & \multicolumn{2}{l}{ Incorrect responses No. \% } \\
\hline 3 & 54.6 & 41 & 45.4 & 34 \\
5 & 65.4 & 49 & 34.6 & 26 \\
7 & 52 & 39 & 48 & 36 \\
2 & 72 & 54 & 28 & 21 \\
7 & 5.4 & 4 & 94.6 & 71 \\
10 & 26.6 & 20 & 73.4 & 55 \\
1 & 10.6 & 8 & 89.4 & 67 \\
5 & 13.4 & 10 & 86.6 & 65 \\
8 & 34.6 & 26 & 65.4 & 49 \\
Total & 37.18 & 251 & 62.82 & 424 \\
\hline
\end{tabular}

The subjects are un aware that "was/were not allowed to" denotes prohibition in the past. Most of the answers involve the use of "might not" which is not normally used to express past prohibition. The subjects generalize the rule that "can" $\rightarrow$ "could", "have" $\rightarrow$ "had" into "may not" $\rightarrow$ "might not".

Thus, it is clear that the subjects fail to produce prohibition at the pragmatic level. Similarly, the responses to items No. 1 and 5 in Q6 show that many subjects are unable to rephrase the notes and sentences in such a way that it gives the meaning of prohibition, because they might not understand the meaning of the original sentence (Table 10): 
Table 10. Subjects' performance of prohibition at the recognition and production levels

\begin{tabular}{|c|c|c|c|c|c|c|c|c|c|}
\hline \multirow{2}{*}{$\begin{array}{l}\text { No. of } \\
\text { Item }\end{array}$} & \multicolumn{2}{|c|}{$\begin{array}{l}\text { Recognition Correct } \\
\text { Responses No. \% }\end{array}$} & \multicolumn{2}{|c|}{$\begin{array}{l}\text { Recognition Incorrect } \\
\text { Responses No. \% }\end{array}$} & \multirow{2}{*}{$\begin{array}{l}\begin{array}{l}\text { No. of } \\
\text { Item }\end{array} \\
3\end{array}$} & \multicolumn{2}{|c|}{$\begin{array}{l}\text { Production Correct } \\
\text { Responses No. \% } \\
\end{array}$} & \multicolumn{2}{|c|}{$\begin{array}{l}\text { Production Incorrect } \\
\text { Responses No. \% }\end{array}$} \\
\hline & 46 & 61.4 & 29 & 38.6 & & 41 & 54.6 & 34 & 45.4 \\
\hline 5 & 61 & 81.4 & 5 & 18.6 & 5 & 49 & 65.4 & 26 & 34.6 \\
\hline 8 & 47 & 62.6 & 28 & 37.4 & 7 & 39 & 52 & 36 & 48 \\
\hline 1 & 54 & 72 & 21 & 28 & 2 & 54 & 72 & 71 & 28 \\
\hline 6 & 27 & 36 & 48 & 64 & 7 & 4 & 5.3 & 71 & 94 \\
\hline 9 & 23 & 30.6 & 52 & 69.4 & 10 & 20 & 26.6 & 55 & 73.4 \\
\hline 1 & 13 & 17.4 & 62 & 87.6 & 1 & 8 & 10.6 & 67 & 89.4 \\
\hline 4 & 18 & 24 & 57 & 76 & 5 & 10 & 13.4 & 65 & 86.6 \\
\hline 7 & 15 & 20 & 60 & 80 & 8 & 26 & 34.6 & 44 & 65.4 \\
\hline Total & 304 & 45.03 & 371 & 54.97 & Total & 251 & 37.18 & 424 & 62.82 \\
\hline
\end{tabular}

After seeing Table 10, it is found that the subjects' performance at the recognition level is better than that at the production level. Still, there is not much difference in the subjects' performance at the two levels. Likewise, their responses to permission, obligation and prohibition, display that there is not much difference between the subjects' performance at the recognition and the production levels. But, in spite of that it could be said that the subjects' performance at the recognition level is better than that at the production level. Furthermore, it is clear that even though the difference between the subjects' performance at permission, obligation and prohibition is not too high, it could be said that their performance of permission is better than that of obligation and prohibition. (Table 11):

Table 11. Comparison of subjects' performance of permission, obligation and prohibition

\begin{tabular}{llllll}
\hline $\begin{array}{l}\text { No. of } \\
\text { item }\end{array}$ & $\begin{array}{l}\text { The Subjects' Responses of } \\
\text { Permission } \%\end{array}$ & $\begin{array}{l}\text { No. of } \\
\text { item }\end{array}$ & $\begin{array}{l}\text { The Subjects' Responses } \\
\text { of Obligation } \%\end{array}$ & $\begin{array}{l}\text { No. of } \\
\text { item }\end{array}$ & $\begin{array}{l}\text { The Subjects' Responses } \\
\text { of Prohibition \% }\end{array}$ \\
\hline 2 & 64 & 3 & 73.4 & 1 & 61.4 \\
4 & 93.4 & 6 & 58.6 & 5 & 81.4 \\
7 & 72 & 9 & 61.4 & 8 & 62.6 \\
2 & 8 & 5 & 0 & 1 & 72 \\
3 & 86.6 & 8 & 76 & 6 & 36 \\
4 & 30.6 & 10 & 34.6 & 9 & 30.6 \\
2 & 82.6 & 3 & 21.4 & 1 & 17.4 \\
5 & 44 & 6 & 25.4 & 4 & 24 \\
9 & 42.6 & 8 & 36 & 7 & 20 \\
1 & 44 & 4 & 42.6 & 3 & 54.6 \\
2 & 40 & 8 & 17.4 & 5 & 65.4 \\
6 & 57.4 & 10 & 10.6 & 7 & 52 \\
4 & 73.4 & 1 & 12 & 2 & 72 \\
5 & 44 & 3 & 69.4 & 7 & 5.3 \\
8 & 40 & 9 & 86.6 & 10 & 26.6 \\
3 & 22.6 & 4 & 22.6 & 1 & 10.6 \\
6 & 56 & 7 & 41.4 & 5 & 13.4 \\
9 & 20 & 10 & 32 & 8 & 34.6 \\
Total & $51.18 \%$ & Total & $40.07 \%$ & Total & 41.11 \\
\hline
\end{tabular}

Moreover, the subjects' responses to the situations of permission, obligation and prohibition in Q4 show that 42.6\% of the subjects use "can", "may", "must", "have to", "must not" and "do not" to produce the aforementioned speech acts.

\subsection{An Analysis of the Relationship among Permission, Obligation and Prohibition}

\subsubsection{The Subjects' Responses of the Relationship among the Speech Acts}

Table 12 illustrates the number and percentage of the correct responses at the recognition level of the relationship among all the speech acts: 
Table 12. Subjects' performance at the recognition level of the relationship among speech acts

\begin{tabular}{lllll}
\hline No .of item & \multicolumn{2}{l}{ Correct Responses No. \% } & \multicolumn{2}{l}{ Incorrect Responses No. \% } \\
\hline 10 & 61 & 81.4 & 14 & 18.6 \\
7 & 26 & 34.6 & 49 & 65.4 \\
4 & 15 & 20 & 60 & 80 \\
Total & 102 & 45.33 & 123 & 54.67 \\
\hline
\end{tabular}

The table indicates that the total percentage of the correct responses at the recognition level is $45.33 \%$. The percentage reveals that many subjects fail to observe the relationship among permission, obligation and prohibition. This indicates that the syllabus has a role in that no attention is given to such a relationship in the grammar courses they study from the first year to the fourth year.

\subsubsection{Subjects' Responses at the Production Level of the Relationship of all Speech Acts}

It is clear out of the table below that the percentage of the subjects' performance at the production level is $44 \%$ (Table 13):

Table 13. Subjects' performance at the production level of relationship among all speech acts

\begin{tabular}{lllll}
\hline No. of item & \multicolumn{2}{l}{ Correct Responses No. \% } & \multicolumn{2}{l}{ Incorrect Responses No. \% } \\
\hline 9 & 33 & 44 & 42 & 56 \\
6 & 29 & 38.6 & 46 & 61.4 \\
2 & 37 & 49.4 & 38 & 50.6 \\
Total & 99 & 44 & 126 & 56 \\
\hline
\end{tabular}

The table shows that the subjects' performance is not too high. The reason behind the subjects' failure in producing the relationship among permission, obligation and prohibition could be related to the subjects' ignorance or to the syllabus in which no space is given for such a notion in the syllabus.

The subjects' responses to the relationship among the types of directives at the recognition and production levels reveal that the percentage of the incorrect responses at the two levels is higher than the correct ones (see tables 12 and 13).

\section{Discussion}

Depending on the data analysis carried out in section 3, the hypotheses are manipulated clearly as follows:

1). The first hypothesis, which states that the subjects' performance at the recognition level is better than that at the production level, is validated.

2). Many responses reveal the subjects' inability to realize and produce permission, obligation and prohibition pragmatically as evident in Q3 and 4. This proves hypothesis No. 2 which states that the Iraqi EFL learners have a low performance at the pragmatic level of permission, obligation and prohibition.

3). Hypothesis No. 3, which says that the subjects' performance of permission at both the recognition and production levels is better than that of obligation and prohibition, is validated.

4). Hypothesis No. 4, which states that the Iraqi EFL learners are unable to realize the relationship among permission, obligation and prohibition, is proved.

5). The fifth hypothesis, which states that the Iraqi EFL learners tend to use particular linguistic forms to express permission, obligation and prohibition is accepted.

\section{Conclusion}

Similarly, surveying the linguistic behavior of permission, obligation and prohibition, and applying the test and analyzing the subjects' responses, the following conclusions are arrived at:

A. The imperative sentence conveys the meaning of permission and prohibition, and the context in which they are used determines the meaning of each one of them.

B. Both of permission and prohibition could be expressed explicitly through the use of performative verbs, and implicitly through the use of modal auxiliaries and imperative sentences.

C. It is found that "will" involves an obligational sense. 
D. Obligation comes in three degrees of duty: weak, medium and strong. "should and ought to" denote weak obligation, "be supposed to and had better" convey medium obligation and "must and have to" express strong obligation. In the same regard, "must not" expresses the meaning of strong prohibition while "may not" and "cannot" have the meaning of the weak one.

E. Past obligation is expressed by "had to", permission in the past is conveyed by "could or was/were allowed to" and past prohibition involves the use of "was/were not allowed to".

F. The relation among permission, obligation and prohibition is that prohibition is seen as the negation of permission and obligation. Also, permission, obligation and prohibition belong to the same class of speech act theory, i.e., directives. Moreover, they are related to the same type modality, i.e., deontic modality.

G. "May" is more formal than "can" in expressing permission, i.e., "may" is mostly used in formal situations while "can" is used in less formal situations.

H. The informants' performance at the recognition and production levels do not reveal a moderate mastering of permission, obligation and prohibition. In spite of that the subjects' recognition performance is better than their production one.

I. Most of the informants' responses are restricted to "can", "may", "must", "have to", "must not" and "do not" when answering the situations of permission, obligation and prohibition.

J. Many of the Iraqi undergraduate informants are unaware that there is a relation among the selected directives.

$\mathrm{K}$. The informants have weaknesses in the pragmatic level of the aforementioned speech acts.

L. The informants do not differentiate between asking and giving permission.

M. The informants are unaware that "indirect Qs" and "will" express a sense of obligation.

N. The informants have not recognized that "may not" and "can not" denote weak prohibition.

O. The informants' performance of permission at the recognition and production level is better than that of obligation and prohibition.

\section{Acknowledgements}

We acknowledge our indebtedness to the subjects of our study, third year students at the Iraqi departments of English for being so helpful with us for responding to our test. In addition, we are indebted to the jury members who contributed to examine the validity and reliability of the test in this study.

\section{References}

Aarts, B. (2001). English Syntax and Argumentation (2nd ed.). London: Palgrave.

Alexander, L. G. (1990). Longman English Grammar Practice. London: Longman.

Allan, K. (1986). Linguistic Meaning. (vol. 2). New York: Longman.

Allen, W. S. (1974). Living English Structure. New York: Longman.

Austin, J. L. (1962). How to Do Things with Words. Oxford: OUP.

Azar, B. S. (2003). Fundamentals of English Grammar (3rd. ed.). London : Longman.

Aziz, Y. (1989). A Contrastive Grammar of English. Mousl: University of Mousl Press.

Bach, K., \& Harnish, R. M. (1979). Linguistic Communication and Speech Acts. Cambridge: The MIT Press.

Berk, L. M. (1999). English Syntax: From Word to Discourse. Oxford: OUP.

Biber, D., Johansson, S., Leech, G., Conrad, S., \& Fingegan, E. (1999). Longman Grammar of Spoken and Written English. London: Longman.

Celce-Murcia, M., \& Larsen-Freeman, D. (1999). The Grammar Book: An ESL/ EFL Teacher's Course (2nd ed.). New York: Heinle and Heinle.

Chalker, S. (1984). Current English Grammar. London: Macmillan.

Clarke, S. (2008). Macmillan English Grammar in Context. London: Macmillan.

Close, R. A. (1987). English as a Foreign Language (2nd ed.). London: Allen and Unwin LTD.

Cruse, A. (2000). Meaning in Language: An Introduction to Semantics and Pragmatics. Oxford: OUP.

Crystal, D. (2003). A Dictionary of Linguistics and Phonetics (5th ed.). London: Blackwell. 
Davies, E. (1986). The English Imperative. London: Croom Helm.

Dixon, R. J. (1987). A complete Course in English. New Delhi: Prentice Hall of India.

Downing, A., \& Locke, P. (2006). English Grammar: A University Course. New York: Routledge

Eastwood, J. (1994). Oxford Guide to English Grammar. New York: OUP.

Eastwood, J. (2009). Oxford Learners' Grammar. Oxford: OUP.

Eckersley, C. E., \& Eckersley, J. M. (1960). A Comprehensive English Grammar for Foreign Students. London: Longman.

Finch, G. (2005). Key Concepts in Language and Linguistics. Hampshire: Palgrave Macmillan Ltd. https://doi.org/10.1007/978-0-230-20445-4

Foley, M., \& Hall, D. (2003). Longman Advanced Learners' Grammar: A self- Study Reference and Practice Book with Answers. London: Longman.

Fowler, R. (1971). An Introduction to TransformationalSyntax. London: Routledge and Kegan Paul Ltd.

Fraser, B. (1987). "Pragmatic Formatives". In J. Verchueren \& M. B. Papi (Eds.), the pragmatic perspective: Selected papers from the 1985 International pragmatics conference (pp. 179-193). Amsterdam: John Benjamins. https://doi.org/10.1075/pbcs.5.14fra

Gethin, H. (1983). Grammar in Context: Proficiency Level English. London: Collins ELT.

Gramley, S., \& Patzold, K. (1992). A Survey of Modern English. London: Routledge. https://doi.org/10.4324/9780203425978

Griffiths, P. (2006). An Introduction to EnglishSemantics and Pragmatics. Edinburgh: EUP.

Grundy, P. (2000). Doing Pragmatics (2nd ed.). London: Arnold.

Halliday, M. K. (1976). Modality and Modulation in English. In Gunther Kress (Ed.), Halliday: System and Function in Language (pp. 189-213). London: OUP.

Halliday, M. K. (1985). An Introduction to FunctionalGrammar. London: Arnold.

Hannouna, Y. H. (2008). English Syntax for EFLCollege Students. Amman: Dar Al- Falah.

Haverkate, H. (1979). Impositive Sentences in Spanish: Theory and Description in Linguistic Pragmatics. Amsterdam: North- Holland Pub. Co.

Hofmann, T. R. (1993). Realms of Meaning: An Introduction to Semantics. London: Longman.

Hornby, A. S. (1968). A Guide to Patterns and Usages in English. London: Longman.

Hornby, A. S., Wehmeier, S., \& Ashby, M. (Eds.). (2000). Oxford Advanced Learners' Dictionary of Current English (8th ed.). Oxford: OUP.

Huang, Y. (2007). Pragmatics. Oxford: OUP.

Huddleston, R. (1988). English Grammar: An Outline. Cambridge: CUP. https://doi.org/10.1017/CBO9781139166003

Hurford, J. R., \& Heasley, B. (1983). Semantics: A Coursebook. Cambridge: CUP.

Jackson, H. (1992). Grammar and Meaning: A Semantic Approach to English Grammar. London: Longman.

Jesperson, O. (1949). A Modern English Grammar on Historical Principles. New York: H. Holt and Company.

Kearns, K. (2000). Semantics. London: Macmillan Ltd.

Kroeger, P. (2005). Analyzing Grammar: An Introduction. Cambridge: CUP. https://doi.org/10.1017/CBO9780511801679

Leech, G., \& Svartvik, J. (1994). A Communicative Grammar of English (2nd ed.). London: Longman.

Levinson, S. C. (1983). Pragmatics. Cambridge: CUP.

Lewis, M. ( 1986). The English Verb. London: CUP.

Lock, G. (1996). Functional English Grammar: An Introduction for Second Language Teachers. Cambridge: CUP.

Lyons, J. (1977). Semantics (Vol. 2). Cambridge: CUP. https://doi.org/10.1017/CBO9781139165693 
Lyons, J. (1995). Linguistic Semantics: An Introduction. Cambridge: CUP. https://doi.org/10.1017/CBO9780511810213

Matthews, P. H. (2007). The Concise Dictionary of Linguistics. Oxford: OUP.

Mey, J. L. (1993). Pragmatics: An introduction. London: Blackwell.

Onions, C. T., \& Miller, B. C. (1971). Modern English Syntax. London: Roultedge and Kegan Paul.

Palmer, F. R. (1965). A Linguistic Study of the English Verb. London: Longman.

Palmer, F. R. (1976). Semantics. Cambridge: CUP.

Palmer, F. R. (1990). Modality and the English Modals. London: Longman.

Palmer, F. R. (1999). Mood and Modality: Basic Principles. In K. Brown \& J. Miller (Eds.), Concise Encyclopedia of Grammatical Categories. New York: Elsevire.

Parker, F., \& Riley, K. (2005). Linguistics for Non-Linguists (4th ed.). London: Pearson

Perkins, M. R. (1983). Modal Expressions in English. London: Pinter.

Praninskas, J. (1975). Rapid Review of EnglishGrammar. New Jersey: Prentice-Hall.

Quirk, R., \& Greenbaum, S. (1990). A Student'sGrammar of the English Language. London: Longman.

Quirk, R., Greenbaum, S., Leech, G., \& Svartvik, J. (1985). A Comprehensive Grammar of the English Language. London: Longman.

Radden, G. (2009). Affirmative and Negated Modality. Retrieved from www.un-hamburg. de/ iaa/modality.pdf

Radden, G., \& Driven, R. (2007). Cognitive English Grammar. Oxford: OUP. https://doi.org/10.1075/clip.2

Sadok, J. (2004). Speech Acts. In Laurence R. H., \& Gregory, W. (Eds.), The Handbook of Pragmatics. New York: Blackwell.

Saeed, J. (1997). Semantics. London: T.J Press Ltd.

Sag, Ivan, A., \& Wasow, T. (1999). Syntactic Theory: A Formal Introduction. Standford: CSLI publications.

Schibsby, K. (1970). A Modern English Grammar. Oxford: OUP.

Schiffer, S. R. (1972). Meaning. Oxford: The Clarendon Press.

Searle, J. R. (1969). Speech acts: An Essay in the Philosophy of Language. Cambridge: CUP.

Searle, J. R. (1969). (1976). A Classification of Illocutionary Acts. In Language in Society, 5(1), 1-24. https://doi.org/10.1017/S0047404500006837

Searle, J. R. (1979). A Taxonomy of Illocutionary acts. In Expression and Meaning: Studies in the Theory of Speech Acts (pp. 1-29). New York: CUP. https://doi.org/10.1017/CBO9780511609213.003

Swan, M. (1995). Practical English Usage (2nd ed.). Oxford: OUP.

Teschner, R. V., \& Evans, E. E. (2007). Analyzing the Grammar of English (3rd ed.). Washington: GUP.

Thomson, A. J., \& Martinet, A. V. (1986). A Practical English Grammar. Oxford: OUP.

Thomson, G. (1996). Introducing Functional Grammar. London: Arnold.

Thomas, J. (1995). Meaning in Interaction: An Introduction to Pragmatics. London: Longman.

Tsohatzidis, S. L. (1987). Deontic Trouble in Speech Act Botany. Analysis, 47(2), 80-83. Retrieved from http://analysis.Oxfordhournals.org/ content/...47/2/80.full.pdf

Vanderveken, D. (1990). Meaning and Speech Acts: Principles of Language use (Vol. 1). Cambridge: CUP.

Verschueren, J. (1999). Understanding Pragmatics. London: Edward Arnold.

Yule, G. (1996). Pragmatics. Oxford: OUP.

Yule, G. (2006). Oxford Practice Grammar. Oxford: OUP.

Zandvoort, R.W. (1975). A Handbook of English Grammar (7th ed.). London: Longman.

\section{Note}

Note 1. Prof. Alaa H. Oda (Ph. D), College of Education, University of Basrah, 
Prof. Riyadh Tariq Kadhim Al-Ameedi (Ph. D), College of Education, University of Babylon,

Asst. Prof. Chasib F. Al-Jubori (Ph. D), College of Ahl- Al Bait, University of Karbala,

Asst. Prof Dhua Attalah Hayder (Ph. D), College of Education, University of Baghdad,

Asst. Prof. Ra'ad Shakir Abdul-Hassan (Ph. D), College of Education for Humanities, University of Thi-Qar, and Lecturer Raheem Khalef Al-Zubaidy (Ph. D), College of education, University of Thi-Qar.

\section{Appendix A}

\section{The Main Test}

Note: -Permission is defined as giving or asking somebody's agreement to do something.

-Obligation is defined as a speaker's intention to oblige someone (not) to do some act.

-Prohibition is defined as a speaker's desire to prevent somebody from doing something.

\section{Q1. Choose the most appropriate answer for each of the following:}

There are many snakes in this area. You come back here anymore.

a- are not b- was not c- can d- never

A permit is a document which states that you do something.
a- must
b- are
c- should
d- are allowed to

The meeting is at 10.30 . you be back at ten o'clock.
a- is
b- might
c- must
d- was

I want to borrow some books. Please ......... someone tell me where the library is?

a- can b- should c- ought to d- need

The boss gives us certain instructions. One of which is that the staff ..... smoke when sewing customers.

a- was not b- shall c- must not d- had not to

The garden is full of grass. I .......... mow it this afternoon.

a- am b-am supposed to c-were d- can not

The doctor gave me a sick- leave. I ........ leave early yesterday.

a- are b- was allowed to c-must d-am

Our neighbor was beaten by a dog last year, so we ....... keep pets in the flat.

a- might b- were not allowed to c-could d- are not

My school was too far. I .......... cycle three miles to school when I was a child.

a- have had to b-had to c-may d- am

You are in need for money. You ....... waste your money on smoking.
a- are not
b- ought not to
c- have to
d- can

\section{Q2. Circle the meaning of each of the following sentences:}

No smoking allowed. (permission, necessity, prohibition, ability).

Would you mind if I opened a window? (obligation, permission, certainty, ability)

I could play football in the garden when I was a child. (permission, necessity, offer, obligation)

Come in. (permission, ability, prohibition, obligation)

I wonder who to invite. (obligation, ability, certainty, permission)

People under eighteen are not supposed to buy alcoholic drinks. (negative permission, negative imperative, prohibition, ability)

My doctor won't let me get up. (imperative, negative obligation, negative permission, certainty)

You are to write your name at the top of each page. (prohibition, permission, obligation, probability)

You have not to park on yellow lines. (obligation, prohibition, suggestion, negative permission) 
You will carefully and clearly give your address and cross the street. (obligation, ability, permission, probability)

\section{Q3. Match the underlined verbs to their meanings:}

\begin{tabular}{|l|l|}
\hline a. it is your duty. & 1. You must not park near a zebra crossing. \\
\hline b. I took permission. & 2. Miss Liu had permission to leave class early. \\
\hline c. The law forbids. & 3. You are supposed to know the laws of your country. \\
\hline d. This is a rule/ law. & 4. You can not stop on a motorway. \\
\hline e. She was allowed to. & 5. Could I borrow your umbrella? \\
\hline f. It is required by official regulations. & 6. Youmust do your homework more carefully. \\
\hline g. You are not allowed. & 7. He is not allowed to talk during the examination. \\
\hline h. Is it ok? & 8. Society's nominating committee shall nominate one person for president. \\
\hline i. It is important. & 9. My parents allow me to stay up late. \\
\hline j. It is restricted by rules. & 10. Youhave to be 18 to be able to vote. \\
\hline
\end{tabular}

\section{Q4. What would you say in each of the following situations?}

1. You are visiting a close friend and you want to have some coffee.

2. You are at a party given by people you hardly know. You want to see their garden.

3. You see your little brother playing with matches. You want to prevent him.

4. you want to tell your friend that it is important for him/her to be at the meeting at six o'clock.

5. You see a man smoking at the hospital. You want to tell him not to do that.

6. You are visiting people you know reasonably well. You want to make a phone call.

7. You see your friends playing football in a restricted area. You want to prohibit them.

8. Your teacher requires you to do page 8 for homework. You want to tell your colleagues about it.

9. Your brother asks for your permission to use your car. You want to refuse.

10. You have not completed your work. Your boss wants you to do it before you leave.

\section{Q5. Do as required:}

He did not pay a visit to his sick uncle. (Obligation in the past).

Prohibit your brother from playing with a knife. ( Use: Do not).

He did not wake up early. (Express obligation using: ought to).

Can I park my car here? (Use : would you mind).

Do you mind if I used your phone? ( Give permission) 
I wonder if I could use your ruler.( Refuse permission)

Guests may use the pool after 11.00 p.m.( Past prohibition)

Can I borrow your camera tomorrow?( Make it more polite)

Oblige Tom to get up early morning.( Express obligation)

10.You may play football in the park on Sundays. (Expressstrong prohibition)

Q6. Rephrase the following sentences and phrases in such a way that is as similar in meaning as possible to the original sentences and phrases:

There is a crocodile in this river.

Fishing is strictly forbidden.

Leave your bag here.

Your room is a mess.

Private_keep out.

Toast and butter are allowed for you.

It is important for everyone to register his/ her name and address in order to be able to vote.

Do not lean out of the window.

Camps allowed.

We have a difficult exam tomorrow and our marks are low in this subject.

\section{Copyrights}

Copyright for this article is retained by the author(s), with first publication rights granted to the journal.

This is an open-access article distributed under the terms and conditions of the Creative Commons Attribution license (http://creativecommons.org/licenses/by/4.0/). 